\title{
LOAD-BEARING CAPACITY OF A RED-YELLOW LATOSOL CULTIVATED WITH COFFEE PLANTS SUBJECTED TO DIFFERENT WEED MANAGEMENTS
}

\author{
Capacidade de suporte de carga de um Latossolo Vermelho-Amarelo cultivado com cafeeiro, \\ submetido a diferentes manejos de plantas invasoras
}

\author{
Paula Sant'Anna Moreira Pais', Moacir de Souza Dias Junior², Adriana Cristina Dias³, \\ Piero Iori², Paulo Tácito Gontijo Guimarães ${ }^{4}$, Gislene Aparecida dos Santos ${ }^{2}$
}

\begin{abstract}
It is essential to know the levels of pressure applied to the soil by different weed managements to adapt the management of coffee plantations in a sustainable manner. The objectives of this study were: a) to generate load-bearing capacity models of a Red-Yellow Latosol (Oxisol) submitted to different weed managements and b) to determine which weed management resulted in higher compression. The study was conducted at the Experimental Farm of EPAMIG, located near the community Farias, in Lavras-MG (latitude $21^{\circ} 14^{\prime} 43^{\prime \prime}$ $\mathrm{S}$ and longitude $44^{\circ} 59^{\prime} 59^{\prime \prime} \mathrm{W}$ and altitude of $919 \mathrm{~m}$ ). The soil is a Red-Yellow Latosol (LVA) cultivated with coffee plantation using Topazio MG 1190 coffee variety, since 2006. We evaluated five weed managements, three being through mechanical control (harrow (GD), mowing (RÇ) and brush (TC)) and two by chemical control (post-emergence herbicide (HPos) and pre emergence herbicide (HPre)). To obtain the load-bearing capacity models, 10 undisturbed soil samples were randomly collected in the 0-3, 10-13 and 25-28 $\mathrm{cm}$ layers between the rows. The load-bearing capacity models which indicated a higher compaction were: in the $0-3 \mathrm{~cm}$ layer, TC and GD; in the 10-13 cm layer, HPre, HPos and RÇ and in the 25-28 cm layer, GD. The load-bearing capacity models that indicated greater susceptibility to compaction were: in the 0-3 cm layer, HPos; in the 10-13 cm layer, GD and TC and in the 25-28 cm layer, HPre.
\end{abstract}

Index terms: Coffee culture, soil compaction, sustainability, preconsolidation stress, soil structure.

\section{RESUMO}

O conhecimento dos níveis de pressão aplicados aos solos pelos diferentes manejos de plantas invasoras é essencial para adaptar o manejo de lavouras cafeeiras de forma sustentável. Os objetivos deste estudo foram: a) gerar os modelos de capacidade de suporte de carga de um Latossolo Vermelho-Amarelo submetido a diferentes manejos de plantas invasoras e b) determinar qual manejo resultou em maior compactação. O estudo foi realizado na Fazenda Experimental da EPAMIG, situada próxima a comunidade Farias, em Lavras-MG (latitude de $21^{\circ} 1^{\prime} 4^{\prime} 43^{\prime \prime} \mathrm{S}$ e longitude $44^{\circ} 59^{\prime}$ '59" W e altitude de $919 \mathrm{~m}$ ). O solo foi classificado como sendo um Latossolo Vermelho-Amarelo o qual vem sendo cultivado com cafeeiros da cutivar Topázio MG 1190, desde 2006. Foram avaliados cinco manejos de plantas invasoras sendo três, por meio do controle mecânico (grade de discos (GD), roçadora (RÇ) e trincha (TC),) e dois, por meio do controle químico (herbicida de pós-emergência (HPós), herbicida de pré-emergência (HPré)). Para a obtenção dos modelos de capacidade de suporte de carga, 10 amostras indeformadas de solo foram coletadas aleatoriamente nas camadas 0-3 e 1013 e 25-28 cm nas entrelinhas do cafeeiro. Os modelos de capacidade de suporte de carga apontaram maior compactação do solo na camada de 0-3 cm para TC e GD; na camada 10-13 cm para HPre, HPos e RÇ e na camada 25-28 cm para GD; e indicaram maior suscetibilidade à compactação na camada de 0-3 cm para HPos; na camada 10-13 cm para GD e TC e na camada 25-28 cm para HPre.

Termos para indexação: Cafeicultura, compactação do solo, sustentabilidade, pressão de pré-consolidação, estrutura do solo.

(Received in december 12, 2012 and approved in february 8, 2013)

\section{INTRODUCTION}

In coffee growing, besides the attention to the constant demands for process and product quality improvements on the part of the domestic and external markets, there is also concern of maintaining the production sustainability, that can be reflected in a higher economic return, higher environmental equilibrium and better social benefits. This sustainability possesses strong dependence on the type of production system used in the crop, whose transport practices enable higher productivity increase, higher cost reduction and better product quality; adjustments in the application of inputs and services being required rationally and frequently (SANTOS, 2004).

The coffee plant is extremely sensitive to infestation and competition of weeds (PAIS et al., 2011; SANTOS et

\footnotetext{
1Universidade Federal de Lavras/UFLA-Departamento de Ciência do Solo/DCS - Cx. P. 3037-37200-000 - Lavras - MG - Brasil - paulaufla@yahoo.com.br Universidade Federal de Lavras/UFLA - Departamento de Ciência do Solo/DCS - Lavras - MG - Brasil

3Universidade Federal de Viçosa/UFV - Viçosa - MG - Brasil

${ }^{4}$ Empresa de Pesquisa Agropecuária de Minas Gerais/EPAMIG - Lavras - MG - Brasil
} 
al., 2009), mainly when they go beyond a particular development stage. In all of the circumstances, control is obligatory and represents a major cost to the operation of the plantation (SOUZA; ALCÂNTARA; MELES, 1978).

Due to that coffee plant sensitivity to weeds, one of the most frequent practices undertaken in coffee growing is weed management (SANTOS et al., 2009).

Weed management in the coffee crop, usually, is related to the use of agricultural machinery that can cause soil compactation (ARAUJO-JUNIOR et al., 2008; DIAS JUNIOR, 2000; DIAS JUNIOR; PIERCE, 1996; LARSON et al., 1989; PAIS et al., 2011; SANTOS et al., 2009; SANTOS et al., 2010), mainly when the management is conducted under inadequate moisture, altering the medium where the root system grows (GYSI, 2001) and promoting soil structure degradation due to the compacting (ARAUJO-JUNIOR et al., $2011 \mathrm{a}$, b; GONTIJO et al., 2008; MARTINS et al., 2012; PIRES et al., 2012; SANTOS et al., 2009; SANTOS et al., 2010), causing crop production reductions.

Several aspects should be considered in the choice of the weed management, thus requiring the elaboration of a plan less impactful to the soil-water-plant system (SANTOS et al., 2009; SANTOS et al., 2010), since the weed management cannot be seen only in terms of water and light competition process between the weeds and the principal culture (FARIA et al., 1998).

Along those lines, it is important to understand how the different weed managements affect the loadbearing capacity of the soils, and its resistance to soil compactation, in order to adapt the coffee crop weed management in a suitable way seeking greater longevity and a higher productivity of the plantation, without causing soil structure degradation (ARAUJO-JUNIOR et al., 2008; ARAUJO-JUNIOR et al., 2011). This is because when the pressure applied by the tractor and implement is greater than the load-bearing capacity of the soil, the result is soil structure degradation.

The objectives of this study were: a) to generate load-bearing capacity models of a Red-Yellow Latosol (Oxisol) submitted to different weed managements and b) to determine which weed management resulted in higher compression.

\section{MATERIAL AND METHODS}

The study was conducted in Experimental Farm of EPAMIG (Minas Gerais Agricultural Research Company), located near the community of Farias, in Lavras-MG, Campo das Vertentes region, latitude $21^{\circ} 14^{\prime} 43^{\prime \prime} \mathrm{S}$ and longitude $44^{\circ} 59^{\prime} 59^{\prime \prime} \mathrm{W}$ Greenwich at an altitude of $919 \mathrm{~m}$.
The climate is the Cwa type, according to the Köeppen classification. The average annual temperature is around $19.3^{\circ} \mathrm{C}$, having average temperatures of $22.1^{\circ} \mathrm{C}$ and $15.8^{\circ} \mathrm{C}$ in the hottest month and coldest month, respectively. The annual precipitation is $1,530 \mathrm{~mm}$, the total evaporation of the year equal to $1,343 \mathrm{~mm}$ and the average annual relative humidity is $76 \%$ (BRAZIL, 1992).

The soil of the area was classified as Red-Yellow Latosol (Oxisol) (LVA) loamy texture (EMPRESA BRASILEIRA DE PESQUISA AGROPECUÁRIAEMBRAPA, 2006).

The study was carried out in a coffee crop (Coffea arabica L.) implanted in 2006, with the Topázio MG 1190 cultivar. The area, before the installation of the experiment, was formed by native pasture, with the presence of some savannah bushes. For the installation of the experiment, cleaning in the area was conducted using a bulldozer and, later, harrowing was conducted with a tractor drawn in the $30 \mathrm{~cm}$ layer.

Five weed managements were appraised, three being through mechanical control; harrow (GD), mowing (RÇ), and brush (TC), and two through chemical control; post-emergence herbicide (HPos), and pre-emergence herbicide (HPre).

All of the equipment used in the mechanical management and chemical control of the weeds were drawn by a Massey Fergusson 275 tractor (approximate mass $3,080 \mathrm{~kg}$ ). The weed mechanical and chemical control operations were conducted whenever $90 \%$ of the area was covered by the weeds and/or they presented about 0.45 m of height (ALCÂNTARA; NÓBREGA; FERREIRA, 2009; ALCÂNTARA; FERREIRA, 2000; ARAUJOJUNIOR et al., 2008) and this occurred more frequently in the rainy season.

In the weed management the following procedures were used: harrow (GD): with 16 disks disposed in a V with an approximate mass of $262 \mathrm{~kg}$ working at $15 \mathrm{~cm}$ of depth. On average, three annual operations were conducted; mower (RÇ): Kamaq KDD 230 ECO Cruiser with hydraulic lift by the power take-off of the tractor, mass approximated at $560 \mathrm{~kg}$. On average, five annual operations were conducted; brush (TC): Tritton 1.300 $\mathrm{RB}$ with six rows of tempered, cast steel, with an approximate mass of $570 \mathrm{~kg}$, with hydraulic lift by the power take-off of the tractor. On average five annual operations were conducted; post-emergence herbicide (HPos): glyphosate alternately with glyphosate $+2,4-\mathrm{D}$, with an average of three applications per year and preemergence herbicide (HPre): Ametryn + Simazine, with an average of two applications a year. 
Undisturbed soil samples were collected in January of 2010, between the rows in the 0-3 cm 10-13 and $25-28 \mathrm{~cm}$ layers in the following manner: 5 managements $x 3$ layers $x$ 10 soil samples with undisturbed structure totaling 150 samples using an Uhland sampler, with volumetric ring of $6.40 \mathrm{~cm}$ of internal diameter by $2.54 \mathrm{~cm}$ of height.

After being collected, the undisturbed samples were wrapped in plastic film and paraffined for preservation of the soil structure and natural humidity.

The excess soil from the top and bottom parts of the undisturbed samples was used in the granulometric analysis, by the pipette method (DAY, 1965) and particles density analysis, by the pycnometer method (BLAKE; HARTGE, 1986).

For obtaining the load-bearing capacity models, the undisturbed samples were saturated and submitted to different tensions with the aid of a suction unit (tensions 2, $-4,-6$ and $-10 \mathrm{kPa}$ ) and the Richards extractor (tensions $33,-100,-500$ and $-1,500 \mathrm{kPa}$ ), thus obtaining different volumetric water contents.

After reaching equilibrium the samples were submitted to the uniaxial compression test (BOWLES, 1986), using a Boart Longyer consolidometer, whose application of the pressure is made through the use of compressed air. The pressure applied to the samples were the following: 25, 50, 100, 200, 400, 800, $1600 \mathrm{KPa}$. These were applied to the samples until $90 \%$ of their maximum deformation was reached (TAYLOR, 1948).

After carrying out the uniaxial compression tests, the pre-consolidation pressures were determined according to Dias Junior and Pierce (1995) based on the soil compression curve. To obtain the load-bearing capacity models, these precompression stress (axis of the ordinates) were represented in function of the volumetric water (axis of the abscissas) using the Sigma Plot software (Jandel Scientific, POWDER Box 7005, San Rafael, CA, USES).

The comparisons of the soil load capacity models were made using the procedure described in Snedecor and Cochran (1989). To obtain the linear models from the exponential model $\left[\sigma_{p}=10^{(a+b \theta)}\right]$, the logarithmic was applied to the precompression stress, resulting in an equation $\log \sigma_{\mathrm{p}}=\mathrm{a}+\mathrm{b} \theta$. The homogeneity tests for linear models compares first the residual variances of the two models, and if theses variances are homogeneous by $\mathrm{F}$ test, then the linear (a) and angular (b) coefficients are compared. If the linear and angular coefficients are not significant by the $\mathrm{F}$ test, the precompression stress and volumetric water content values are grouped together and a new equation is then adjusted to these values. However, if the linear (a) and/or angular (b) coefficients differ significantly, the precompression stress and volumetric water content values are grouped. Another condition in which the values of precompression stress and volumetric water contents are not grouped occurs when the residual variances of the two models are homogeneous.

\section{RESULTS AND DISCUSSION}

The homogeneity tests of the load-bearing capacity models performed according to the procedure described in Snedecor and Cochran (1989) are presented in table 1.

The of load-bearing capacity models $\left[\sigma_{p}=10^{(a+b \theta)}\right]$ of LVA for the different weed managements in the layers of $0-3,10-13$ and $25-28 \mathrm{~cm}$, are presented in figure 1 . The "a" values (linear regression intercept) varied from 2.70 to 3.58 , and those of " $b$ " (linear regression angular coefficient), between -1.31 and -3.80 . The coefficients of determination $\left(\mathrm{R}^{2}\right)$ were all significant to $1 \%$ by the Student-t test and varied from 0.80 to 0.97 .

The load-bearing capacity models of the $0-3 \mathrm{~cm}$ layer, for the weed control managements conducted with TC and GD were homogeneous (Table 1). Due to that, a new equation was obtained for those managements considering all the values of $\sigma_{\mathrm{p}}$ and $\theta$, obtaining a single model for TC and GD (Figure 1a). The load-bearing capacity models of the weed control managements conducted with HPre, HPos and RÇ, in the 0-3 cm layer were statistically different (Table 1) indicating different load-bearing capacities for each one.

In the $0-3 \mathrm{~cm}$ layer, the weed managements conducted with GD and TC, in general, were those that presented higher load-bearing capacity. Similar results for the management with GD in the $0-3 \mathrm{~cm}$ layer were observed by Araujo-Junior et al. (2011).

That higher load-bearing capacity for the management with GD could have been associated to the $1.30 \mathrm{~m}$ width of the harrow cut, insufficient for the effective control of the weeds in only one pass through the interrow, provoking an increase of the traffic intensity (annual operations were conducted, while in weed management with chemical control 2 or 3 annual operations were conducted) and soil compactation in the center of the interrow. Besides the intensity of the operations, the higher exposure of the soil to the direct impact of rain drops and the drying and wetting cycles provide the emergence of crusts that increases the pre-consolidation pressure (ARAUJO-JUNIOR et al., 2008). This crusting is characterized by high bulk density, little porosity and low hydraulic conductivity (SILVA; KATO, 1997), interfering in the compressive behavior of the soil and hence the precompression stress, resulting in a higher load bearing 
capacity of the soil (ARAUJO-JUNIOR et al., 2008). The higher load-bearing capacity in TC can also be explained by the intensity of the traffic ( 5 annual operations were conducted), necessary for weed management (ARAUJOJUNIOR et al., 2008; SILVA et al., 2006).

The management of weeds most susceptible to compactation, in the $0-3 \mathrm{~cm}$ layer, was with HPos. This is because the mulch cover provided by the management with HPos protects the soil against erosion and preserves its moisture, thus contributing to the system sustainability
(ARAUJO-JUNIOR et al., 2008), providing a better structure to the soil, reducing its load-bearing capacity and mechanical resistance. As such, it can be indicated that the use of the HPos management provides good plant covering in the inter rows of coffee plant crops, with the objective of reducing the physical degradation and water and soil losses (BERTONI; LOMBARDI NETO, 1999; FARIA et al., 1998; PROCHNOW et al., 2005). The managements with HPre and RÇ, obtained an intermediate behavior regarding the load-bearing capacity.

Table 1 - Comparison of the load-bearing capacity models at 0-3 cm, 10-13 cm and 25-28 cm layers for a Red-Yellow Latosol cultivated with coffee and submitted to different weed managements according to the procedure described in Snedecor and Cochran (1989).

\begin{tabular}{|c|c|c|c|}
\hline \multirow{2}{*}{ Weed Management } & \multirow{2}{*}{$\mathrm{F}$} & \multicolumn{2}{|c|}{$\mathrm{F}$} \\
\hline & & Angular coefficient, $b$ & Linear coefficient, a \\
\hline \multicolumn{4}{|c|}{$0-3 \mathrm{~cm}$} \\
\hline TC x GD & $\mathrm{H}$ & ns & $\mathrm{ns}$ \\
\hline $\mathrm{TC}$ and $\mathrm{GD} \times \mathrm{RÇ}$ & $\mathrm{H}$ & $* *$ & $* *$ \\
\hline TC and GD x HPos & $\mathrm{H}$ & $*$ & $* *$ \\
\hline TC and GD x HPre & $\mathrm{H}$ & $* *$ & ns \\
\hline $\mathrm{RÇ} x$ HPos & $\mathrm{H}$ & $*$ & $* *$ \\
\hline RÇ x HPre & $\mathrm{H}$ & $*$ & ns \\
\hline HPre x HPos & $\mathrm{H}$ & ns & $* *$ \\
\hline \multicolumn{4}{|c|}{$10-13 \mathrm{~cm}$} \\
\hline HPre $\mathrm{x}$ HPos & $\mathrm{H}$ & ns & ns \\
\hline HPre and HPos x RÇ & $\mathrm{H}$ & ns & ns \\
\hline HPre and HPos and RÇ x GD & $\mathrm{H}$ & ns & $* *$ \\
\hline HPre and HPos and $\mathrm{RC} \times \mathrm{TC}$ & $\mathrm{H}$ & $* *$ & $* *$ \\
\hline GD $\times \mathrm{TC}$ & & $* *$ & ns \\
\hline \multicolumn{4}{|c|}{$25-28 \mathrm{~cm}$} \\
\hline GD x HPre & $\mathrm{H}$ & $* *$ & $* *$ \\
\hline GD x HPos & $\mathrm{H}$ & $* *$ & ns \\
\hline GD x RÇ & $\mathrm{H}$ & ns & $* *$ \\
\hline GD $x$ TC & $\mathrm{H}$ & $*$ & $\mathrm{~ns}$ \\
\hline HPre x HPos & $\mathrm{H}$ & ns & $* *$ \\
\hline HPre x RÇ & $\mathrm{H}$ & $*$ & ns \\
\hline HPre $x$ TC & $\mathrm{H}$ & ns & $* *$ \\
\hline HPos x RÇ & $\mathrm{H}$ & $* *$ & $* *$ \\
\hline HPos x TC & $\mathrm{H}$ & $*$ & $\mathrm{~ns}$ \\
\hline RÇ x TC & $\mathrm{H}$ & ns & $* *$ \\
\hline
\end{tabular}

$\mathrm{H}$ : homogeneous; F: F test; $*$ significant at $5 \%$;* significant at $1 \%$; ns: not significant. 

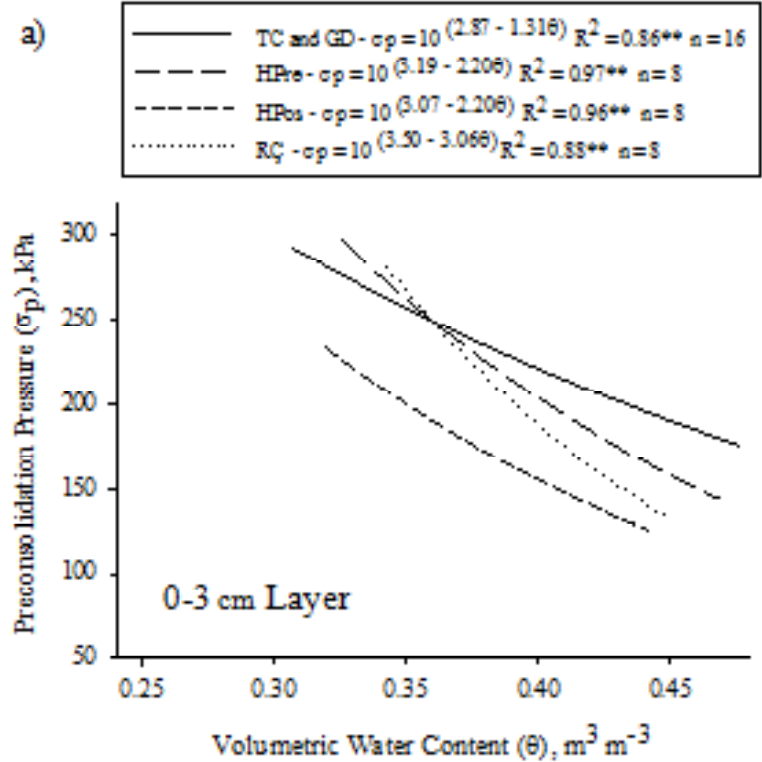

b)
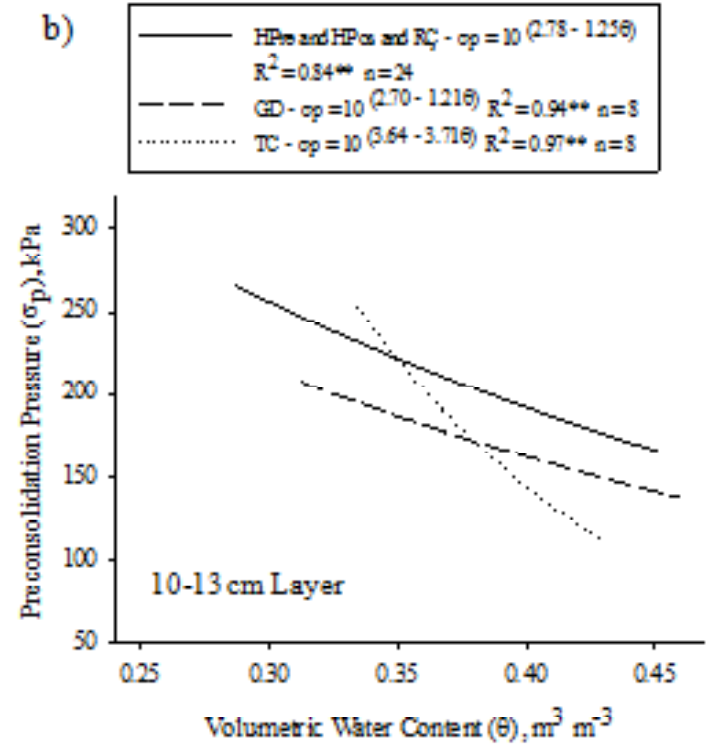

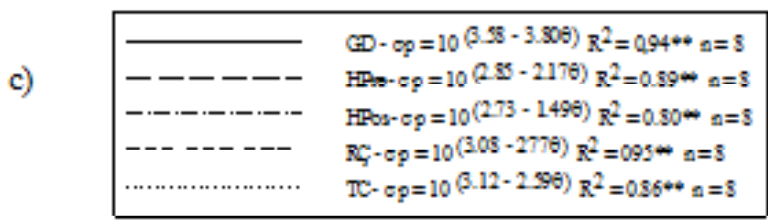

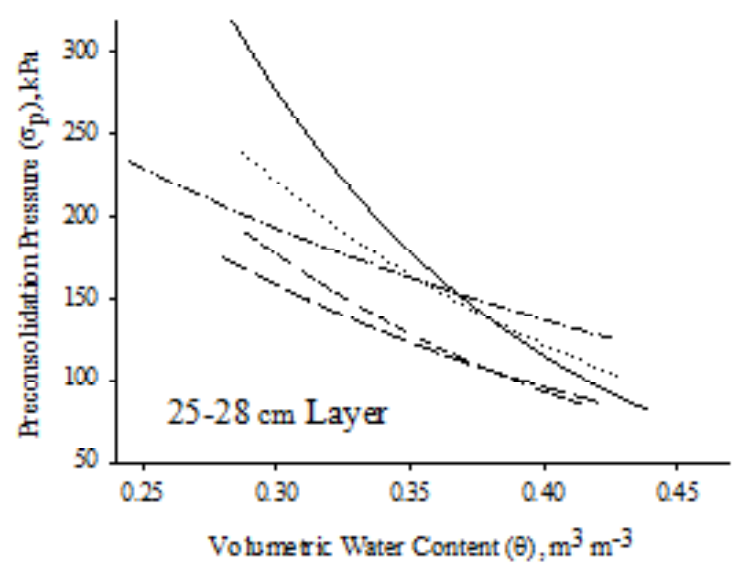

Figure 1 - Load-bearing capacity models of the 0-3 cm, 10-13 cm and 25-28 cm layers for a Red-Yellow Latosol cultivated with coffee and submitted to different weed managements.

Comparing the all of the load-bearing capacity models for the 10-13 cm layer (Table 1), we verified that the HPre, HPos and RÇ managements models were homogeneous. Due to that, was a new equation adjusted, considering all the values of $\sigma_{\mathrm{p}}$ e $\theta$, obtaining a single load-bearing capacity model for HPre, HPos and RÇ (Figure 1b). Compared this model with the models of the other managements, they were statistically different (Table 1) indicating different load-bearing capacities.

In Figure $1 b$, it can be seen that in the $10-13 \mathrm{~cm}$ layer, the managements that presented higher load-bearing capacity, and, therefore more resistant to compactation, in general, were conducted with with HPre, HPos and RÇ, similar were obtained by Araujo-Junior et al. (2011) for management with HPre, RÇ and by Kurachi and Silveira (1984) for RÇ.

Ciênc. agrotec., Lavras, v. 37, n. 2, p. 145-151, mar./abr., 2013 
The managements carried out with GD for moistures lower than $0.38 \mathrm{~m}^{3} \mathrm{~m}^{-3}$ and TC with moistures above $0.38 \mathrm{~m}^{3} \mathrm{~m}^{-3}$, presented lower load-bearing capacity and, therefore, higher susceptibility to compacting.

The load-bearing capacity models for the $25-28$ $\mathrm{cm}$ layer, were not homogeneous (Table 1) indicating different load-bearing capacities.

In the $25-28 \mathrm{~cm}$ layer (Figure 1c), the weed managements conducted with GD was, in general, that which promoted higher load-bearing capacity. This higher load-bearing capacity obtained in the management with GD is probably the result of the increase of the compacting below the working depth of the harrow disks (SOUZA; MELLES, 1986) that in the case of the weed management, was conducted to $15 \mathrm{~cm}$ of depth. This degradation of the structure provoked by GD causes the soil to have a high load-bearing capacity.

The weed management that presented lower loadbearing capacity and therefore, lower resistance to compacting was HPre (Figure 1c). This can be explained by the fact that the constant use of HPre and the exposure of the soil to the impact of the rain drops enhance the soil surface sealing (ARAUJO-JUNIOR et. al., 2008; ALCÂNTARA; FERREIRA, 2000; BERTONI; LOMBARDI NETO, 1999; FARIA et al., 1998). Due to the pore blockage caused by the surface sealing in the $0-3 \mathrm{~cm}$ layer, the water loss by evaporation is less, therefore keeping the lower layers more humid and less subject to the wetting and drying cycles, making the moisture more uniform and thus diminishing the natural mechanical resistance of the soil (ARAUJO-JUNIOR et al., 2008; MIRANDA et al., 2003; SILVA et al., 2006.

The other weed managements, HPos, RÇ and TC, obtained intermediate behavior in relation to the loadbearing capacity.

\section{CONCLUSIONS}

The load-bearing capacity models that indicated higher soil compactation were: in the $0-3 \mathrm{~cm}$ layer, TC and GD; in the 10-13 cm layer, HPre, HPos and RÇ and in the 25$28 \mathrm{~cm}$ layer, GD.

The load-bearing capacity models that indicated higher susceptibility to compactation were: in the $0-3 \mathrm{~cm}$ layer, HPos; in the 10-13 cm layer, GD and TC and in the 25$28 \mathrm{~cm}$ layer, HPre.

\section{ACKNOWLEDGEMENTS}

The authors would like to thank FAPEMIG, CNPq, Capes, Embrapa Café and EPAMIG, for funding the work.

\section{REFERENCES}

ALCÂNTARA, E.N.; FERREIRA, M.M. Efeito de métodos de controle de plantas invasoras na cultura do cafeeiro (Coffea arabica L.) sobre a qualidade física do solo. Revista Brasileira de Ciência do Solo, Viçosa, MG, v.24, n.4, p.711-721, out./dez. 2000.

\section{ALCÂNTARA, E.N.; NÓBREGA, J.C.A.; FERREIRA,}

M.M. Métodos de controle de plantas daninhas no cafeeiro afetam os atributos químicos do solo. Ciência Rural, Santa Maria, v.39, n.3, p.749-757, maio/jun. 2009.

ARAUJO-JUNIOR, C. F. et al. Capacidade de suporte de carga e umidade crítica de um Latossolo induzida por diferentes manejos. Revista Brasileira de Ciência do Solo, Viçosa, v.35, n.1, p.115-131, jan./fev. 2011.

ARAUJO- JUNIOR, C. F. et al. Resistência à compactação de um Latossolo cultivado com cafeeiro, sob diferentes sistemas de manejo de Plantas invasoras. Revista Brasileira de Ciência do Solo, Viçosa, v.32, n.1, 23-32, jan./fev. 2008.

BLAKE, G.R.; HARTGE, K.H. Particle density. In: KLUTE, A. (ed). Methods of soil analysis. 2.ed. Madison, ASA/SSSA, 1986. Part 1, p.377-382.

BRASIL. Ministério da Agricultura e Reforma Agrária. Normais climatológicas 1961-1990. Brasília: MARA, 1992, $84 \mathrm{p}$.

BERTONI, J.; LOMBARDI NETO, F. Conservação do solo. 4.ed. São Paulo: Ícone, 1999, 355p.

BOWLES, J.E. Engineering properties of soils and their measurements. 3. ed. New York, McGraw Hill, 1986, 218p.

DAY, P.R. Particle fractionation and particle-size analysis. In: BLACK, C.A., ed. Methods of soil analysis. Madison, ASA/SSSA. 1965. Part 1, p.545-567.

DIAS JUNIOR, M. de S. Compactação do solo. In: NOVAIS, R. F.; ALVAREZ, V. H. V.; SCHAEFER, C. E. G. R. Tópicos em ciência do solo. Viçosa, MG: Sociedade Brasileira de Ciência do Solo, 2000, p.55-94.

DIAS JUNIOR, M.S.; PIERCE, F.J. A simple procedure for estimating preconsolidation pressure from soil compression curves. Soil Technology, Amsterdam, v.8, n.2, p139-151, nov. 1995. 
DIAS JUNIOR, M.S.; PIERCE, F.J. Revisão de literatura: o processo de compactação do solo e sua modelagem. Revista Brasileira de Ciência do Solo, Campinas, v. 20, n. 1, p. 175-182, jan./mar. 1996.

\section{EMPRESA BRASILEIRA DE PESQUISA AGROPECUÁRIA - EMBRAPA. Centro Nacional de Pesquisas de Solos. Sistema Brasileiro de Classificação de Solos. 2. ed. Rio de Janeiro, Embrapa Solos, 2006, 306p.}

FARIA, J. C. et al. Effects of weed control on physical and micropedological properties of brazilian Ultisol.

Revista Brasileira de Ciência doSolo, Viçosa, MG, v.22, n.3, p.731-741, jul./set. 1998.

GONTIJO, I. et al. Atributos físico-hídricos de um Latossolo de Cerrado em diferentes posições de amostragem na lavoura cafeeira. Revista Brasileira de Ciência doSolo, Viçosa, v.32, n.6, p.2227-2234, nov./dez. 2008.

GYSI, M. Compaction of a Eutric Cambisol under heavy wheel traffic in Switzerland: field data and a critical state soil mechanics model approach. Soil and Tillage

Research, Amsterdam, v.61, n.3/4, p.133-142, sept. 2001

KURACHI, S. A. H.; SILVEIRA, G. M. da. Compactação do solo em cafezal provocada por diferentes métodos de cultivo. Campinas-SP, 1984, 28 p. (IAC- Boletim do Instituto Agronomico de Campinas).

LARSON, W. E. et al. Mechanics and related processes in structured agricultural soils. Amsterdam: Kluwer Academic, 1989, 273 p. (Nato Applied Science, 172).

MARTINS, P.C.C. et al. Compaction caused by mechanized operations in a Red-Yellow Latosol cultived with coffee over time. Ciência e Agrotecnologia, Lavras, v.36, n.4, p.391-398, 2012.

MIRANDA, E. E. V. et al. Efeito do manejo e do tráfego nos modelos de sustentabilidade da estrutura de um Latossolo Vermelho cultivado com cafeeiros. Ciência e Agrotecnologia, Lavras, Edição Especial, p.1506-1515, dez. 2003.

PAIS. P.S.M. et al. Compactação causada pelo manejo de plantas invasoras em Latossolo Vermelho-Amarelo cultivado com cafeeiros. Revista Brasileira de Ciência do Solo, Viçosa, v.35, n.6, p.1949-1957, nov./dez. 2011.
PIRES, B.S. et al. Modelos de capacidade de suporte de carga de um Latossolo Vermelho-amarelo sob diferentes usos e manejos. Revista Brasileira de Ciência do Solo, Viçosa, vol.36, n.2, p. 635-642, mar./abr. 2012.

PROCHNOW, D. et al. Razão de perdas de terra e fator C da cultura do cafeeiro em cinco espaçamentos, em Pindorama (SP), Revista Brasileira de Ciência do Solo, Viçosa, v.29, n.1, p.91-98, jan./fev. 2005.

SANTOS, G.A. et al. Weed management and its influence on the load bearing capacity of Red-Yellow Latosol under the crown projection in coffee culture. Coffee Science, Lavras, v.4, n.2, p.165-177, jul./dez. 2009.

SANTOS, G.A. et al. Suscetibilidade à compactação de um Latossolo Vermelho-Amarelo submetido a diferentes métodos de controle de plantas invasoras, na cultura cafeeira. Coffee Science, Lavras, v.5, n.2, p.123-136, maio/ago. 2010.

SANTOS, J. C. F. et al. Cobertura do solo no controle de plantas daninhas no café. Porto Velho-RO, 2004. 33p. (Embrapa Rondônia. Documentos, 87).

SILVA, A. R. et al. Modelagem da capacidade de suporte de carga e quantificação dos efeitos das operações mecanizadas em um Latossolo Amarelo cultivado com Cafeeiros. Revista Brasileira de Ciência do Solo, Viçosa, v.30, n.2, p.207-216, mar./abr. 2006.

SILVA, C. L.; KATO, E. Efeito do selamento superficial na condutividade hidráulica saturada da superfície de um solo sob cerrado. Pesquisa Agropecuária Brasileira, Brasília, v.32, n.2, p.213-220, fev. 1997.

SNEDECOR, G W.; COCHRAN, W. G. Statistical methods. 8.ed. Iowa State University Press. 1989, 503p.

SOUZA, I. F.; MELLES, C. C. A. Controle de plantas daninhas. In: RENA, A. B. et al. (Ed.). Cultura do cafeeiro: fatores que afetam a produtividade. Piracicaba: POTAFOS, 1986, p.401-409.

SOUZA, I. F.; ALCÂNTARA, E. N.; MELLES, C. C. A. Controle de ervas daninhas. Informe Agropecuário, Belo Horizonte, v.4, n.44, p.56-66, 1978.

TAYLOR, D. W. Fundamentals of soil mechanics. New York, John Wiley \& Sons, Inc., 1948, 700 p. 